\title{
An Investigation of Conceptual Metaphors Denoting "Life" in American and Vietnamese Short Stories
}

\author{
Dinh Thi Mai Anh \\ Vinh University \\ E-mail: maianhdinh@vinhuni.edu.vn
}

Received: 24 May 2017; Revised: 24 May 2017; Accepted: 24 May 2017

\begin{abstract}
Metaphor has attracted the attention of linguist for more than 2000 years (Ning Yu, 1998). Traditionally, metaphor was viewed as a matter of language, only used in literature to embellish discourse (Kövecses, 2010). However, cognitive linguistics presents a different view of metaphor, stating that metaphor is pervasive and essential in language and thought (Lakoff \& Johnson, 1980). It is defined as understanding one abstract conceptual domain (target domain), in terms of another concrete one (source domain). The concept of life has been one of the most common target domains, which is hard to be fully comprehended without establishing a set of mappings, i.e. a set of systematic correspondences, between this undeliberated notion and other better-known ones. Therefore, this study attempts to probe into conceptual metaphors denoting "life" in nineteen American and nineteen Vietnamese short stories from 1975 to 1991 in the light of Lakoff and Johnson's framework (1980). The two sets of collected data, specifically 89 illustrations in English and 114 in Vietnamese, are compared and contrasted to find out the similarities and differences in the use of these conceptual metaphors between two languages to contribute to foreign language teaching, learning, and translating process.
\end{abstract}

Key words: conceptual metaphor; life; english; vietnamese;

\section{Introduction}

Cognitive linguistics is the approach to the study of language that began to emerge in the 1970 s and has been increasingly active since the 1980s. Until now, a large amount of research has been carried out in the light of cognitive linguistics over the world in general and in Vietnam in particular, and most of them have focused on semantics with a deeper insight into the use of conceptual metaphor in language. Conceptual metaphors involve two concepts and have the form $\mathrm{A}$ is $\mathrm{B}$, where the more abstract concept A such as love, life, economy and argument is comprehended in terms of the more concrete concept B including war or a container. Therefore, the investigation of conceptual metaphors with the aim to find out similarities and differences of using this kind of meaning transference among languages in the world brings great benefits to the English teaching, learning, and translating process.

Life has been one of the most inspirational and enchanting topics for thousands of writers across the time. Although the concept 
of life is commonly mentioned in our daily life or everyday conversations, its definition or true meaning cannot be described by only one or two words. For instance, imagine life is a game. People are considered as players, who need to play as skillfully and fairly as they can with the aim to win, or acquire their own goals in life. If the concept of life is perceived in terms of a journey, people are considered as travellers trying their best to overcome all impediments on their way to reach the final destinations. As a result, the abstract concept of life can be metaphorically mentioned through other more delineated ones. Depending on the distinctive features of different cultures or specific geographical characteristics of regions in the world, life has its own uniqueness.

The research entitled "An investigation of conceptual metaphors denoting "life" in American and Vietnamese short stories" is conducted to contribute to the process of understanding and interpretation of conceptual metaphors in American and Vietnamese short stories.

In Metaphors We Live By (1980), Lakoff and Johnson present their strong arguments against the traditional view of metaphor and introduce a new one that challenged all the aspects of this widely-share theory in a coherent and systematic way. They claim "metaphor is pervasive in everyday life, not just in language but in thought and action" (Lakoff \& Johnson, 1980, p.3). They also introduce the notion of conceptual metaphor and illustrate their viewpoint with a huge number of linguistic examples. This work is the main theoretical background and guideline for my study.

Since then, a considerable number of researches have been carried out in the light of cognitive linguistics in the world and in Viet Nam as well. In Lakoff and Turner's work (1989), More than Cool Reason: A field guide to poetic metaphor, the conceptual metaphors denoting "life" were mostly examined on the scope of poems. Other minor researches on the concept of life includes The Journeys of Life: Examining a Conceptual Metaphor with Semantic and Episodic Memory Recall (Katz \& Taylor, 2008) with a deeper insight into only one conceptual metaphor LIFE IS A JOURNEY. This conceptual metaphor is also dicussed by
Lakoff (1994) and Winter (1995). In Viet Nam, there are some noticeable cognitive linguists, such as Lý Toàn Thắng (2005), Trần Văn Cơ (2007), Nguyễn Đức Tồn (2007, 2009), Phan Văn Hoà (2008) and Nguyễn Lai (2009). Lý Toàn Thắng (2005) in his book "Ngôn ngữ học tri nhận - Từ lý thuyết đại cương đến thực tiễn tiếng Việt" gives an introduction to cognitive linguistics and presents distinctive features of linguistic models about the world. Trần Văn Cơ (2007) explains the traditional view of metaphor and points out the new viewpoint on this figure of speech in the light of cognitive linguistics. Nguyễn Đức Tồn (2008) and Nguyễn Lai (2009) do research on the use of conceptual metaphors in idioms and poetry respectively.

In general, none of researches have been carried out to examine conceptual metaphors denoting life in American and Vietnamese short stories during the period of time 1975 - 1991, which motivates me to make an investigation in this topic.

In this study, the researcher attempts to give answers to the following questions: (1) How are the conceptual metaphors of life conceptualized in American and Vietnamese short stories from 1975 to 1991 ? (2) What are the similarities and differences of the conceptual metaphors denoting life in American and Vietnamese short stories from 1975 to 1991? (3) What are the implications for the use of conceptual metaphors in teaching, learning, and translating?

\section{Material and Methods}

In this research, both the quantitative and qualitative method are used in the process of analyzing the collected data. Contrastive and Comparative Analysis are utilized with the aim to find out the similarities and differences of conceptual metaphors denoting life in American and Vietnamese short stories.

The quantity of metaphorical expressions denoting life found is the exact number of 203 samples, specifically 114 lexical units in Vietnamese, and 89 illustrations in English. The two sets of data are analyzed and compared on the basis of the classification of conceptual metaphors introduced by Lakoff and Johnson (1980) in their famous work Metaphor: We Live $B y$. There are three different kinds of conceptual 
metaphors, specifically structural metaphors, ontological metaphors and orientational metaphors.

Lakoff and Johnson (1980) explain that in structural metaphors, "one concept is metaphorically structured in terms of another" (p.14). Ontological metaphors relate to our experience of physical objects and substances, which allows us to pick out parts of our experience and treat them as discrete entities. As a result, "we can refer to them, categorize them, group them, and quantify them - and by this means, reason about them." (p.25). Orientational metaphors deal with "spatial orientation: up-down, in-out, front-back, on-off, deepshallow, central-peripheral" (p.14).

In order to achieve the aims of this study, the data are both quantitatively and qualitatively analyzed. Firstly, the quantitative method is used to give statistic results of the collected data. To be more specific, the data are examined in terms of the frequencies of structural, ontological, and orientational metaphors in the nineteen American and nineteen Vietnamese short stories. Secondly, the qualitative method is applied to analyze and evaluate the collected data into conceptual metaphors denoting life, as follows:

LIFE IS A JOURNEY

LIFE IS A WAR

LIFE IS AN ENTITY

LIFE IS A PERSON

LIFE IS A STORY

LIFE IS A PAIN

\section{Results and Discussion Similarities}

In both languages, the more abstract concept of life are commonly perceived in terms of the more concrete ones including a journey, passing of time, a war, a story, a game, an entity, a container, a personal possession, and a machine. The evidences show that the highest frequency of occurrence belongs to the ontological metaphors in both languages, accounting for an impressive percentage of 55.2 with 112 samples out of 203 illustrations in total. The quantity of structural metaphors makes up the second highest proportion of 44.8 with 91 examples. However, there is no metaphorical expression denot- ing orientational metaphors found on the scope of this study in both languages.

Regarding the ontological metaphors, the conceptualization LIFE IS AN ENTITY is the most common one in both languages. On the basis of our practical knowledge about physical objects and substances, both American and Vietnamese people tend to identify our experiences as entities. With such understanding, "we can refer to them, categorize them, group them, and quantify them - and, by this means, reason about them" (Lakoff \& Johnson, 1980, p. 25). To be more specific, an entity is a tangible and visible object, or a physical item. It is connected with things that actually exist or are present; and can be seen and felt rather than things that only exist in a person's mind such as the notion of life. In contrast, life is an abstract term, which merely can be understood based on general ideas and not on any particular real person, thing or situation. It normally exists in thought or as an idea but not having a physical reality. In other words, this concept does not represent people or things in a realistic way. Therefore, in order to refer to, quantify or classify life, both American and Vietnamese people conceive it in terms of an entity. Common expressions in both languages are a life (môt đời), many lives (nhiều đời), and thousands of lives (nghin đòi). Life can be categorized into various types such as a sexual life (đời sống tình dục), a spiritual life (đời sống tinh thần), a practical life (đời sống thực tiễn), a miserable life (đời sống khốn khổ), a city life (đời sống đô thị, đời sống thị thành), a private life (đời tur, cuộc đời riêng), a political life (đời sống chính trị), a harmonious life (đời sống hoà đồng), a new life (cuộc sống mới), a past life (đời sống quá khứ), and an impoverished life (cuộc sống nghèo khố). Some aspects of life are also mentioned, such as the hardship of life (cái khắc nghiệt của đời).

Life is conceptualized as a container and found in both languages. With our perception of people's body as a container with in-out orientation, other abstract notions are also comprehended according to this way. In both American and Vietnamese people's mind, life is used to store things, and even we can go into and go out of it. The typical examples of this type are in life (trong đời, ở đời), into life (vào đời), wipe something/ somebody out of life (xoá cái gì đó/ ai đó ra khỏi cuộc sống), disappear from life 
(biến mất khỏi cuộc sống), come back into life (quay trở lại với cuộc sống), erase somebody/ something from life (xoá bỏ ai đó/ cái gì đó khỏi cuộc sống), and full of (đầy).

The conceptual metaphor LIFE IS A PERSONAL POSSESSION is commonly expressed in both languages. Each person always considers life as his or her own things. Therefore, American people tend to put possessive adjectives such as my, our, his, her, their before the abstract noun of life, in order to show their ownership, while in Vietnamese, they use the word của to represent this relationship, as in examples cuộc sống của mẹ con Thắm, đời của lão, số phận của lão, của vợ chồng, con cái lão.

In regards to structural metaphors, life is conceived in terms of a journey in both languages. The American use the verbs such as be lost, turn, swerve, and veer off to show the motion of travellers on their life journey, while in Vietnamese, common ones include đi chuyến đi cuối cùng của cuộc đời, đi gần hết cuộc đời, and đi qua đời. In addition, way and track are usually found in American expressions, while Vietnamese ones consist of phrases such as khúc đường đời, quãng đời, đường đời, đoạn đời, and nẻo đường.

Lifetime is comprehended as passing of time in both languages. People's lives are considered as a series of days or years, with prevalent American lexical units such as ten years of my life, another day in my life, over the last ten years, in the seven years that remained of his life, and the last year of the old man's life; and common Vietnamese ones such as bẩy chục năm đã sống, sống cô độc những năm về cuối, sống tròn bảy chục năm, mỗi ngày một khép kín của đời lão, những ngày cuối đời của lão, and sống thêm mươi năm nữa. On the base of all the illustrations found in American and Vietnamese short stories, it is believed that most of expressions used to talk about life come from the ways people mention about the passing of time.

The conceptual metaphor LIFE IS A MACHINE is also found in American and Vietnamese. The American use the verb break to indicate the state of life being damaged and stopping working, while Vietnamese people have the word hỏng with the same meaning. In particular, when talking about the broken state of life, the American tend to mention about the ways or the proper tools to fix, repair, remedy or mend it. The samples denoting this kind of conceptual metaphor found in Vietnamese short stories merely account for an insignificant percentage of 1.0, in comparison with others.

Life can be understood through the more concrete notion of a war. On the verge of death and life, the American have to mobilize their strength and fight for their own lives. Similarly, Vietnamese people also try their best to undergo a life battle (trải qua một trận xáo trộn đời sống) in order to survive or be alive in this world.

LIFE IS A STORY is another common conceptual metaphor, with American metaphorical expressions such as stories about life, and make a perfect little story, and Vietnamese ones including thứ chuyện đầy hấp dẫn về đời sống, mẩu chuyện tâm sự về đời tư, kể đời mình, kể nghe vài đoạn đời, and đời chẳng ít chuyện trớ trêu. Both American and Vietnamese people consider life as a story containing interesting and unpredictable circumstances, which can be told and shared with other people.

The illustrations showing the way of understanding life through the notion of game only take up a small percentage compared with others in both languages. While American people play with life as a dice game, Vietnamese ones conceive life as một cuộc chơi phàm tục or một cuộc chơi sinh thú.

On the scope of this study, no data illustrating the orientational metaphors can be found in both languages.

\section{Differences}

It is observed that Vietnamese shares with English all the basic metaphor source domains for life. However, a metaphor that Vietnamese has, but English does not, is LIFE IS A PAIN, accounting for $2 \%$ with 4 illustrations. The reasons for the presence of this conceptual metaphor might be predictable on the base of Vietnamese historical context at that period of time. On April $30^{\text {th }}, 1975$, it marked the event when Viet Cong and North Vietnamese troops captured Saigon (now known as Ho Chi Minh city), which is called as Reunification Day, Victory Day, Liberation Day, or the official name of Day of liberating the South for national reunification. This victory put an end to the Vietnam War, also known as the 
American War, which occurred in Vietnam, Lao, and Cambodia from November $1^{\text {st }}, 1955$ to the fall of Saigon on April 30 ${ }^{\text {th }}, 1975$. During this devastating war, thousands of innocent people were killed, and a significant number of families in Viet Nam were broken by those lives lost. Vietnamese people had to suffer from severe pains that could not be described in words. Coming from this war, despite all the happiness and pride of the victory against a strong and powerful country as America, Vietnamese citizens must deal with negative results of the war such as starvation, innocent death, disability, poverty, violence, reduction to population, destruction of resources, and crash of economy. Their lives after the Reunification Day, or more specifically from 1975 to 1991 were extremely hard and indigent, which was closely and faithfully reflected in literature in general, and in Vietnamese short stories in particular. That might be the reasonable explanation for the association between life and a pain, or the presence of the life-related expressions around the concept of pains.

Another noticeable difference of life conceptual metaphors in two languages is that while there are 7 lexical units derived from LIFE IS A PERSON in the collected American data, no expressions manifested from this conceptualization are found in the Vietnamese short stories. This might be because of the distinctive features of cultural values between two countries. Americans strongly believe in the concept of individualism. To be more specific, they consider themselves to be separate individuals who are in control of their own lives, rather than members of a close-knit, interdependent family, religious group, tribe, nation, or other group. Meanwhile, the most important factor in the value system of the Vietnamese is the family. The family is the center of the Vietnamese common man's preoccupation and the backbone of Vietnamese society. By virtue of the principle of collective and mutual responsibility, each individual strives to be the pride of his family. These core values in American and Vietnamese culture may affect the languages used in literature and everyday life as well, which leads to the differences in using conceptual metaphors denoting life between them. That the American value the individualism may explain the reason why the metaphorical expressions manifested from LIFE IS A PERSON are found in the short stories. Each life is also considered as a person who can independently make his own decision. In contrast, the Vietnamese society is deemed to be more traditional or family-oriented; therefore, there are no expressions derived from this conceptual metaphor.

\section{Conclusion}

This research is carried out with the hope to strengthen the theory of cognitive linguistics in general, and cognitive semantics in particular. Besides, the researcher also hopes to find out the similarities and differences of conceptual metaphors denoting "life" in American and Vietnamese short stories from 1975 to 1991 . On the basis of all the analysis above, it is obvious that the abstract concept of life is commonly perceived in terms of other more concrete ones in both languages. There are some similar conceptual metaphors found in American and Vietnamese corpus analyzed in the study, including LIFE IS AN ENTITY, LIFETIME IS PASSING OF TIME, LIFE IS A JOURNEY, LIFE IS A CONTAINER, LIFE IS A PERSONAL POSSESSION, LIFE IS A MACHINE, LIFE IS A WAR, LIFE IS A STORY, and LIFE IS A GAME. Regarding the differences, the most noticeable one is that there are no metaphorical expressions manifested in LIFE IS A PAIN found in American short stories, while no evidences show that LIFE IS A PERSON exists in Vietnamese ones. This may be because of the different cultural and historical background of two countries.

\section{Suggestion}

Hopefully, the findings of this study will bring students a number of benefits in their learning process, as follows.

Firstly, metaphor can aid the development of reading skills. Empirically, Boers (2000) found that students who had access to the original literal use of the figurative vocabulary were better at figuring out the author's opinion than those provided with synonyms of the target language items. Therefore, after reading this research, students may have a basis knowledge about conceptual metaphor theory, and understand more about the representations of conceptual metaphors 
denoting "life" in English and Vietnamese, which facilitates their process of reading other materials related to this field, and as a result, benefit their reading comprehension in general.

Secondly, thanks to understanding metaphorical expressions in both languages, learners will become more interested into reading original texts or works in English, which creates a great opportunity to broaden their vocabulary source, especially figurative expressions. Working with metaphorical language, learners can understand the making of meaning and sense, and thus can acquire an effective way of learning to improve their language proficiency.

Lastly, when students have a solid knowledge of conceptual metaphor theory, and a wide range of metaphorical expressions, they will be able to produce metaphors to serve different purposes in life. Most scholars tend to be cautious regarding learners' production of figurative language. The argument has been that foreign language learners often need to comprehend metaphors more than produce them (Littlemore \& Low, 2006, p. 46; Low, 2008, p. 222). Kecskés and Papp (2000) even explicitly caution learners against the use of metaphors because this is a communicative risk. However, Lakoff and Johnson (1980) emphasize the ubiquity of metaphors in everyday's life. Recently, MacArthur's (2010) paper also expresses a strong interest in learners' productive metaphors. She highlights the benefits of encouraging metaphor production, and points out that metaphor is the most powerful tool to make meaning from everyday words.

\section{References}

Adams, A. \& Kenison, K. (1991). The Best American Short Stories. New York: Houghton Mifflin Company.

Boers, F. (2000). Enhancing metaphoric awareness in specialized reading. English for Specific Purposes, 19(2), 137-147.

Dinh T. T. \& Nguyen K. T. (2008). Truyện ngắn chọn lọc Ma Văn Kháng. [The collection of Ma Van Khang short stories]. Hanoi: Liturature Publishing House.

Katz, A. N. \& Taylor, T. E. (2008). The journeys of life: Examining a Conceptual
Metaphor with Semantic and Episodic Memory Recall. Metaphor and Symbol, 23, 148-173.

Kecskés, I., \& Papp, T. (2000). Metaphorical competence in trilingual language production. In J. Cenoz \& U. Jessner (Eds.), English in Europe: The acquisition of a third language (pp. 99-120). Clevedon: Multilingual Matters.42.

Kövecses, Z. (2010). Metaphor: A Practical Introduction. Oxford: Oxford University Press.

Lakoff, G. \& Johnson, M. (1980). Metaphors We Live By. Chicago: The University of Chicago Press, Ltd.

Lakoff, G. \& Turner, M. (1989). More than Cool Reason: A field guide to poetic metaphor. Chicago: University of Chicago Press.

Littlemore, J., \& Low, G. (2006). Figurative thinking and foreign language learning. Basingstoke: Palgrave Macmillian.

Low, G. (2008). Metaphor and education. In R. Gibbs (Eds.), The Cambridge handbook of metaphor and thought (pp. 212-231). Cambridge, New York: Cambridge University Press.

Ly, T. T. (2005). Ngôn ngũ hoc tri nhận - Tù lý thuyết đại cuoong đến thực tiến tiếng Việt [Cognitive Linguistics - From theory to practice in Vietnamese]. Phuong Dong Publishing House.

MacArthur, F. (2010). Metaphorical competence in EFL: Where are we and where should we be going? A view from the language classroom. AILA Review, 23(1), 155-173.

Ning Yu. (1998). The Contemporary Theory of Metaphor: A Perspective from Chinese (Human Cognitive Processing series, 1). Amsterdam and Philadelphia: John Benjamins.

Ngo V. B. (2015). Xuân Thiều toàn tập, tập 3. [Xuan Thieu collection: Volumn 3]. Hanoi: Liturature Publishing House.

Nguyen P. H. \& Nguyen K. T. (2003). Nguyến Khải: Truyện ngắn 1. [Nguyen Khai: Short stories 1]. Hanoi: Liturature Publishing House.

Nguyen, D. T. (2007). Bản chất của ẩn dụ. [The nature of metaphor]. Linguistic Journal, 
$10,11$.

Nguyen, D. T. (2008). Đặc trưng tư duy của người Việt qua ẩn dụ tri nhận trong thành ngũ. [The characteristics of Vietnamese thinking through Cognitive Linguistics expressed in idioms]. Linguistic Journal, 1.

Nguyen, L. (2009). Suy nghĩ về ẩn dụ khái niệm trong thế giới thi ca từ góc nhìn của ngôn ngữ học tri nhận. Linguistic Journal, 10.

Phan, V. H. (2008). Ẩn dụ, ẩn dụ dụng học và ẩn dụ ngũ̃ pháp. [Metaphor, Pragmatic metaphor, Grammatical metaphor]. Linguistics and Life Journal, 5.

Thanh, T. \& Nguyen, V. (2007). Truyện ngắn Nguyễn Minh Châu - Tác phẩm và lò̀i binh. [Nguyen Minh Chau's short stories - Works and Comments]. Hanoi: Liturature Publishing House.

Tran, V. C. (2007). Ngôn ngũ học tri nhận: Ghi chép và suy nghĩ. [Cognitive Linguistics: Notes and Thinking]. Social Science Publishing House.

Updike, J. \& Kenison, K. (1999). The Best American Short Stories of the Century. New York: Houghton Mifflin Company. 